\title{
A Comparison of the Physico-Chemical and Bacteriological Quality of Greywater from Water Deficient Households in Homabay Town and Githurai Estates in Kenya
}

\author{
Victor G. Nganga, Francis W. Kariuki* and Kiplagat Kotut \\ Department of Plant and Microbial Science, P.O. Box 43844 GPO 00100 Nairobi, Kenya
}

\begin{abstract}
Greywater, the untreated household wastewater that has not been contaminated by toilet waste, has been touted as a reliable all year-round source of water, especially in water scarce areas. Although it is commonly reused in water scarce urban and peri-urban settlements in Kenya, information on its bacteriological and physico-chemical properties is generally limited. The present study sought to compare the physico-chemical and bacteriological quality of kitchen and laundry greywater from an urban (Githurai) and peri-urban settlement (Homabay). Compared to the source water, kitchen and laundry greywater at the two sites had higher electrical conductivity (EC) and salinity, depressed dissolved oxygen (DO) levels and a wide $\mathrm{pH}$ range. Although significant differences in EC, DO and salinity of greywater from kitchen and laundry were noted $(\mathrm{P}<0.05)$, the two sites differed significantly only in DO $(\mathrm{P}=0.002)$. Total coliforms $(\mathrm{TC})$ and fecal coliforms (FC) were also higher in greywater than in source water. The greywater types differed in TC $(\mathrm{P}=0.003)$ while the two sites differed in both TC and FC $(\mathrm{P} \leq 0.03)$. High loads of TC and FC suggest possible fecal contamination of greywater. This coupled with the occasional presence of Salmonella, Shigella and Vibrio cholerae means that reuse of untreated greywater is not safe in both sites, and should be treated before use. Owing to the differences in the quality of the different types of greywater as well as the sites investigated, the design of greywater treatment technologies should consider both type and source.
\end{abstract}

Keywords: Greywater, homabay, githurai, coliforms, salmonella, shigella, vibrio.

\section{INTRODUCTION}

Water availability is essential for socio-economic development [1]. Unfortunately, the quantity of freshwater available worldwide is fast declining hence the need for more efficient use of the available water [2]. Currently, the number of people living under water stress is about 700 million and this number is projected to reach the 3 billion mark in 2035 [3]. It is further projected that in the next 50 years, more than $40 \%$ of the world's population will be found in countries facing water stress or water scarcity [1]. As part of ongoing efforts to increase the efficiency of water use, re-use of treated wastewater, especially from domestic sources, has been suggested as a reliable alternative source of water [4-6]. Presently, re-use of wastewater for irrigation, landscape and surface or groundwater replenishment is widely practiced $[4$, $7,8]$. The motivations for recycling wastewater are manifold and can include alleviating water shortages caused by either low rainfall or excessive demand as a result of environmental and economic drivers [9]. Use of wastewater in agriculture, aquaculture and other settings also reduces the need for artificial fertilizer and contributes to nutrient cycling [1].

*Address correspondence to this author at the Department of Plant and Microbial Science, P.O. Box 43844 GPO 00100 Nairobi, Kenya; Tel: +254 0721 457747; Fax: +254-020-811575/811242;

E-mails: franciskrk@yahoo.com or francis.kariuki2@gmail.com
Wastewater from domestic sources comprises greywater and blackwater [10]. Greywater is domestic wastewater that includes water from domestic cleaning operations such as bathing, cleaning dishes and washing clothes [11-13] while blackwater is wastewater from toilets. Greywater is generally perceived to be the cleaner of the domestic wastewater [11, 2] and constitutes 50 to $80 \%$ of the wastewater generated by households [14-16]. The volume of greywater generated varies widely depending on water availability. In poor areas where water is often hand carried from taps, it may be as low as 20 to 30 liters per day. However, with an increase in water availability, the production of greywater increases up to about 100 liters per day in developing countries [1]. According to the United States Environment Protection Agency [17], greywater can be used untreated, or it can be treated to varying degrees to reduce nutrients and disease-causing microorganisms. In some rural areas of Jordan, greywater is used directly for irrigating fruit trees without any kind of treatment [18]. Hence greywater re-use is widely considered to be the potential solution for the provision of non-potable water to water deprived regions worldwide [19]. However, there are constraints associated with the direct reuse of greywater that may significantly reduce the chances of a successful implementation of any reuse strategy [11]. The main hazard is infections associated with pathogenic microorganisms such as Salmonella typhimurium, Campylobacter jejuni, Giardia intestinalis and Cryptosporidium parvum 
[20]. These microorganisms are introduced into greywater through fecal cross-contamination [21]. Hence the appropriate use of greywater depends on both the source of greywater and the level of treatment [11]. Among the various uses, use of greywater reuse for toilet flushing has been reported to be without a health risk if treated prior to reuse [22].

In general, greywater reuse offers several advantages that include saving money spent by water authorities on clean water supplies, reducing sewage flows as well as reducing the public demand on potable water supplies. By reusing greywater, the load on wastewater disposal systems is reduced, and therefore, the life of the wastewater disposal system is prolonged and capital expenditure required for the upgrading and expansion of systems is delayed [1]. In Mexico, the problem of blue green algae in sewerage ponds and water reservoirs is significantly reduced by household reuse of greywater while in South African urban areas; greywater reuse has increased water savings and reduced household expenses [14]. The mushrooming of informal settlements in most cities of developing countries has led to the scarcity of essential services including the supply of safe water for domestic use and a sewerage system for waste disposal. In Kenya, the problem is most acute in semi arid areas such as Homabay town and in poorly planned informal sectors of urban areas such as Githurai Estate in Nairobi. Owing to the insufficient supply of water, direct re-use of greywater is a common practice in these areas. Despite the widespread direct reuse of greywater in informal settlements in Kenya, information on the quality greywater generated is generally scarce. Preliminary findings on the bacteriological quality and physico-chemical properties of the greywater produced have indicated that greywater generated in Homabay is generally to contaminated with enteric bacteria and further that pathogenic bacteria frequently occur in greywater samples [23]. Hence the reuse of greywater in Homabay has a potential human health risk. However, more information is required before it can be reliably confirmed that the greywater properties reported for Homabay town apply to similar settlements in different settings in the country.

The aim of this paper is to compare and discuss the general characteristics of greywater produced by water deficient households in informal settlements, one in a peri urban and the other in an urban locality. The results presented serve to provide baseline information on the challenges and risks associated with reuse of untreated greywater. The data presented forms the basis by which policy makers can formulate guidelines on reuse of greywater and also inform the design and development of greywater treatment technologies that can be applied in different locational and environmental settings.

\section{MATERIALS AND METHODS}

\section{Study Sites}

The study was carried out in Githurai Estate in Nairobi city and Homabay town in Homabay County. Although the two sites experience frequent water shortages, the inhabitants of the two sites differ in lifestyle and livelihood. Whereas the residents of Homabay are largely influenced by the rural lifestyles, those of Githurai have less contact with the rural

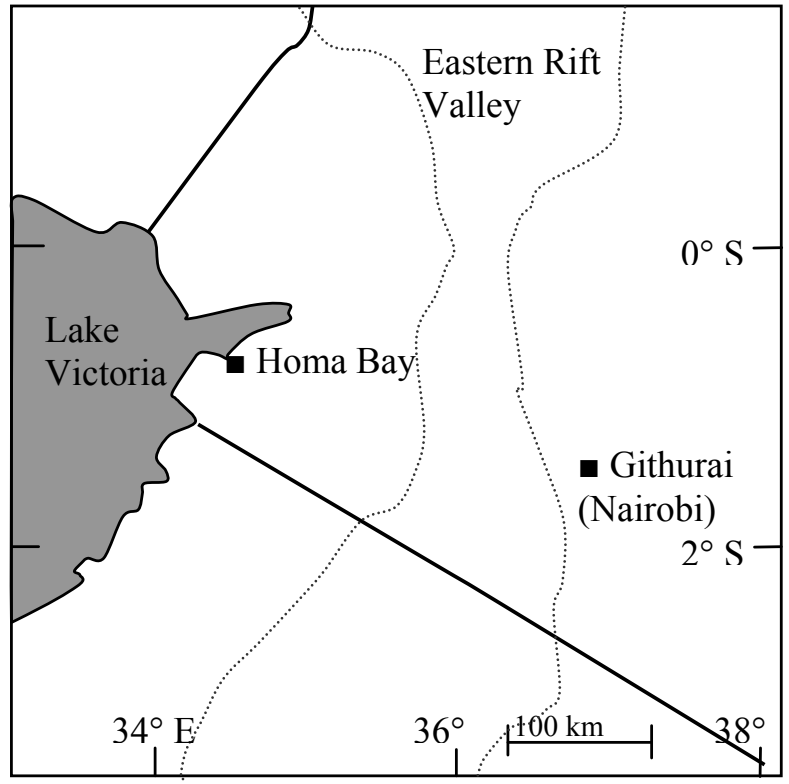

Fig. (1). Map of south western Kenya showing the approximate location of Homabay and Githurai study sites.

lifestyle and are comparatively more urban. Homabay Town is located along the north - eastern shore of Lake Victoria, approximately $105 \mathrm{~km}$ south of Kisumu City and some 405 $\mathrm{km}$ southwest of Nairobi City (Fig. 1). The town ranks as one of the poorest districts in Kenya with over $70 \%$ of its population categorized as living below the poverty line. The main source of water for this town is Lake Victoria. Other sources include, shallow wells, springs and boreholes. Water shortage in Homabay town stems from an unreliable rainfall and a water supply system that can only supply about $40 \%$ of the total water requirements. This coupled with an irregular and a disproportionate supply system that does not favor informal settlements makes water deficiency very acute in such settlements. Githurai is located on the eastern side of Nairobi city, $20 \mathrm{~km}$ from the city centre, along the NairobiThika Highway. The estate is a typical example of estates within the city that receive inadequate supply of water. As is the case with most city estates, Githurai has experienced rapid population growth that is exerting pressure on the existing water supply. Most of the residents do not receive enough water to meet their domestic demands and have to rely on water vendors to meet the deficit. The existing water supply system was designed to serve a population of 30,000 people, but now the population is well over 100,000 people.

\section{Study Methods}

\section{Sample Collection and Data Analysis}

Greywater samples were collected early in the morning when cleaning in most households was at its peak. Ten households were selected randomly in each study area during each visit as described in kotut et al. [23]. Five households provided greywater from the kitchen dishwashing and five from laundry cleaning. At each sampling site, the sample bottles were opened under the greywater in a suitable container, filled up and closed under water. Once collected, the samples were appropriately fixed in the field and transported 
in an ice cooled cool box to the water research laboratory at the Department of Plant and Microbial Sciences in Kenyatta University. Bacteriological examination of the samples commenced within six hours after sampling. In cases where immediate laboratory analysis was not possible, the samples were held at $4^{\circ} \mathrm{C}$ until the time of analysis.

A comparison of mean values of the parameters investigated in the greywater types collected at the two sites (Homabay kitchen, Homabay laundry, Githurai kitchen and Githurai laundry) was carried out using a one way ANOVA test. Where a significant mean difference was noted, mean separation using the least significant difference (LSD) technique was carried out.

\section{Physico-Chemical Properties}

Determination of $\mathrm{pH}$, conductivity, salinity and dissolved oxygen was carried out in the field using a suitable probe of a Multiline P4 (WTW, Weilheim-Germany) conductivity meter. Once the water sample was collected, a suitable amount was gently transferred to an appropriate container into which Multiline probes for the measurement of each of the above attributes was lowered into the sample and allowed to stabilize for a few minutes after which the reading was taken.

\section{Bacterial Load}

The analysis of water for the presence and quantity of total coliforms and fecal coliforms was carried out using the membrane filter technique (MF). To determine the total coliforms counts, an amount of $100 \mathrm{ml}$ of greywater sample was aseptically filtered with the aid of a vacuum pump through an aseptic membrane filter with a pore size of 0.45 $\mu \mathrm{m}$. The filter was then aseptically transferred from the filtration assembly into a petri dish containing LES-Endo agar [24]. After incubation at $35^{\circ} \mathrm{C}$ for 24 hours, the bacteria colonies on the membrane filter were counted using a colony counter. To estimate the fecal coliforms counts, an amount of $100 \mathrm{ml}$ of greywater sample was aseptically filtered through a membrane filter. The membrane filter was then aseptically transferred to a sterile snap lid petri dish containing m-FC broth [25]. The petri dish was sealed with a waterproof tape, inverted, placed in watertight plastic bag, and incubated in a water bath at $44.5{ }^{\circ} \mathrm{C}$ for 24 hours. The fecal coliform density was recorded as the number of colonies per $100 \mathrm{~mL}$ [25].

\section{Pathogenic Bacteria}

\section{Salmonella and Shigella}

Screening for the presence of Salmonella and Shigella was carried out in three successive stages. The first stage of selective enrichment was done using the tetrathionate broth base. An amount of one $\mathrm{mL}$ greywater sample was mixed with $10 \mathrm{~mL}$ of tetrathionate broth and the mixture incubated at $35^{\circ} \mathrm{C}$ for 24 hours. After incubation, a loopful of the broth was carefully streaked on a petri-plate containing Salmonella-Shigella (SS) agar and incubated at $37{ }^{\circ} \mathrm{C}$ for 24 hours. Suspect colonies were subjected to various biochemical procedures to confirm their presence. First, the colonies from the presumptive test were streaked on Triple-Sugar-Iron (TSI) agar slants and incubated for 24 hours at $37{ }^{\circ} \mathrm{C}$. Fur- ther confirmation involved a serological activity test. One drop of the suspected colony was placed on to a white ceramic tile and a drop of the respective thoroughly shaken antiserum added and stirred using a sterile applicator. The tile was rotated slowly and examined for clumping after 1-2 minutes [25].

\section{Vibrio Cholerae}

Presence of Vibrio cholerae was determined in three successive stages. An amount of $1 \mathrm{~mL}$ sample was enriched in sterile alkaline peptone water dispensed in $10 \mathrm{~mL}$ tubes and incubated for 18 hours at $35^{\circ} \mathrm{C} \mathrm{[25].} \mathrm{A} \mathrm{loopful} \mathrm{of} \mathrm{the} \mathrm{broth}$ was then carefully streaked on a petri-plate containing Thiosulfate Citrate Bile Salts Sucrose (TCBS) agar and incubated at $35^{\circ} \mathrm{C}$ for 24 hours [26]. Serological tests were carried out to confirm the suspect colonies [25]. This involved introducing a colony of suspected $V$. cholera onto a white ceramic tile followed by one drop of thoroughly shaken antiserum suspension. The ceramic tile content was mixed by stirring with a suitable sterile applicator stick.

\section{RESULTS}

\section{Physico-Chemical Properties}

Electrical conductivity (EC) of greywater samples from Homabay ranged from 60 to $4470 \mu \mathrm{S} \mathrm{cm}^{-2}$ while at Githurai the range was from 114 to $4650 \mu \mathrm{S} \mathrm{cm}^{-2}$ (Table 1, Fig. 2). At both sites, the lowest EC was recorded during the rainy season month of April while the highest EC was recorded during the dry season. In Homabay mean EC of greywater from kitchen and laundry cleaning were 818.3 and $1472 \mu \mathrm{S} \mathrm{cm}$ respectively while in Githurai the mean values were 789.1 (kitchen) and 1538.5 (laundry) (Table 1). Laundry greywater had the highest mean EC at the two study sites (Githurai $1538 \mu \mathrm{S} \mathrm{cm}^{-2}$; Homabay - $1472 \mu \mathrm{S} \mathrm{cm}^{-2}$ ). Mean EC for clean water sources at Homabay and Githurai were 162.3 and $151.2 \mu \mathrm{S} \mathrm{cm}^{-2}$ respectively. A comparison of mean EC of the greywater types from the two sites (Homabay kitchen, Homabay laundry, Githurai kitchen and Githurai laundry) using a one way ANOVA revealed that the difference in EC was significant $(P=0.002$, df 135). Mean separation using the least significant difference (LSD) technique at $\mathrm{P}=0.05$ revealed that laundry greywater had a significantly higher EC than kitchen greywater. Comparing mean EC of the two sites using a t-test revealed that the difference in EC of greywater samples from Githurai and Homabay was not significant ( $P$ $=0.203$, df 137).

The salinity of greywater samples from Homabay and Githurai ranged from below the limit of detection (reported as $0.0 \mathrm{mg} \mathrm{L}^{-1}$ ) to maximum values of 2.3 (Homabay) and 1.5 (Githurai) $\mathrm{mg} \mathrm{L}^{-1}$. Salinity values of clean water samples were below the limit of detection at both sites (Tables 1). Mean salinity of greywater from kitchen and laundry cleaning at Homabay were 0.2 and $0.6 \mathrm{mg} \mathrm{L}^{-1}$ respectively while at Githurai, the mean values were 0.3 and $0.6 \mathrm{mg} \mathrm{L}^{-1}$ in the same order (Table 1). As in the case of EC, laundry greywater generally had higher salinity values than kitchen greywater. A comparison of the mean salinity of greywater samples from the two sites using the ANOVA test revealed that the salinity difference was significant $(P=0.02, \mathrm{df}=135)$. Mean separation using the LSD technique revealed that laundry 
Table 1. Physico-Chemical Properties, Total Coliform and Fecal Coliform Counts of Greywater and Source (Clean) Water Samples from Homabay and Githurai. Greywater Samples were Collected from Kitchen and Laundry Cleaning

\begin{tabular}{|c|c|c|c|c|c|c|c|}
\hline \multirow{2}{*}{\multicolumn{2}{|c|}{ Property/Type }} & \multicolumn{3}{|c|}{ Homabay } & \multicolumn{3}{|c|}{ Githurai } \\
\hline & & \multirow{2}{*}{$\begin{array}{c}\text { Source } \\
162\end{array}$} & \multirow{2}{*}{$\begin{array}{c}\text { Kitchen } \\
818 \mathrm{~b}\end{array}$} & \multirow{2}{*}{$\begin{array}{c}\text { Laundry } \\
1472 \mathrm{a}\end{array}$} & \multirow{2}{*}{$\begin{array}{c}\text { Source } \\
151\end{array}$} & \multirow{2}{*}{$\begin{array}{c}\text { Kitchen } \\
789 \mathrm{~b}\end{array}$} & \multirow{2}{*}{$\frac{\text { Laundry }}{1539 \mathrm{a}}$} \\
\hline Conductivity $\mathrm{S} \mathrm{cm}^{-2}$ & Mean & & & & & & \\
\hline & Range & $143-187$ & $60-4110$ & $225-4470$ & $135-175$ & $114-1503$ & $175-4650$ \\
\hline \multirow[t]{2}{*}{ Salinity $\mathrm{mg} \mathrm{L}^{-1}$} & Mean & 0 & $0.2 \mathrm{~b}$ & $0.60 \mathrm{a}$ & 0 & $0.29 \mathrm{~b}$ & $0.61 \mathrm{a}$ \\
\hline & Range & $0-0$ & $0-2.1$ & $0-2.3$ & $0-0$ & $0.0-1.5$ & $0.0-0.6$ \\
\hline \multirow{2}{*}{ Diss. oxygen mg L ${ }^{-1}$} & Mean & 5.7 & $3.5 \mathrm{~b}$ & $3.7 \mathrm{~b}$ & 6.2 & $4.4 \mathrm{ab}$ & $5.2 \mathrm{a}$ \\
\hline & Range & $4.5-7.1$ & $0.0-6.9$ & $0-7.96$ & $4.1-7.7$ & $2.46-7.31$ & $1.97-7.64$ \\
\hline \multirow{2}{*}{$\mathrm{pH}$} & Median & 7.3 & 8.4 & 9.2 & 7.2 & 8.15 & 8.84 \\
\hline & Range & $6.7-7.5$ & $5.0-10.2$ & $7.3-10.3$ & $6.8-7.3$ & $5.3-10.1$ & $4.5-10.0$ \\
\hline \multirow{2}{*}{ Temperature ${ }^{\circ} \mathrm{C}$} & Mean & 23.7 & 26.2 & 24.9 & 23.4 & 24.4 & 24.9 \\
\hline & Range & $20.0-27.6$ & $13.6-22.8$ & $13.9-27.8$ & $21-27.4$ & $15.3-25.7$ & $23.5-26.4$ \\
\hline \multirow{2}{*}{ Tot. coliforms CFU x $10^{6}$} & Mean & 1.70 & $4.30 \mathrm{~b}$ & $4.20 \mathrm{~b}$ & 1.30 & $5.23 \mathrm{a}$ & $5.35 \mathrm{a}$ \\
\hline & Range & $1.3-2.4$ & $1.3-7.6$ & $1.6-7.4$ & $1.1-1.9$ & $3.3-6.5$ & $2.8-7.8$ \\
\hline \multirow{2}{*}{ Fecal coliforms CFU $\times 10^{5}$} & Mean & 0 & 3.22 & 2.1 & 0 & 1.5 & 1.1 \\
\hline & Range & 0 & $0.049-6.2$ & $0.029-7.4$ & 0 & $0.032-5.6$ & $0.029-6.2$ \\
\hline
\end{tabular}

NB: Means with same letter where not significant based on the LSD mean separation technique

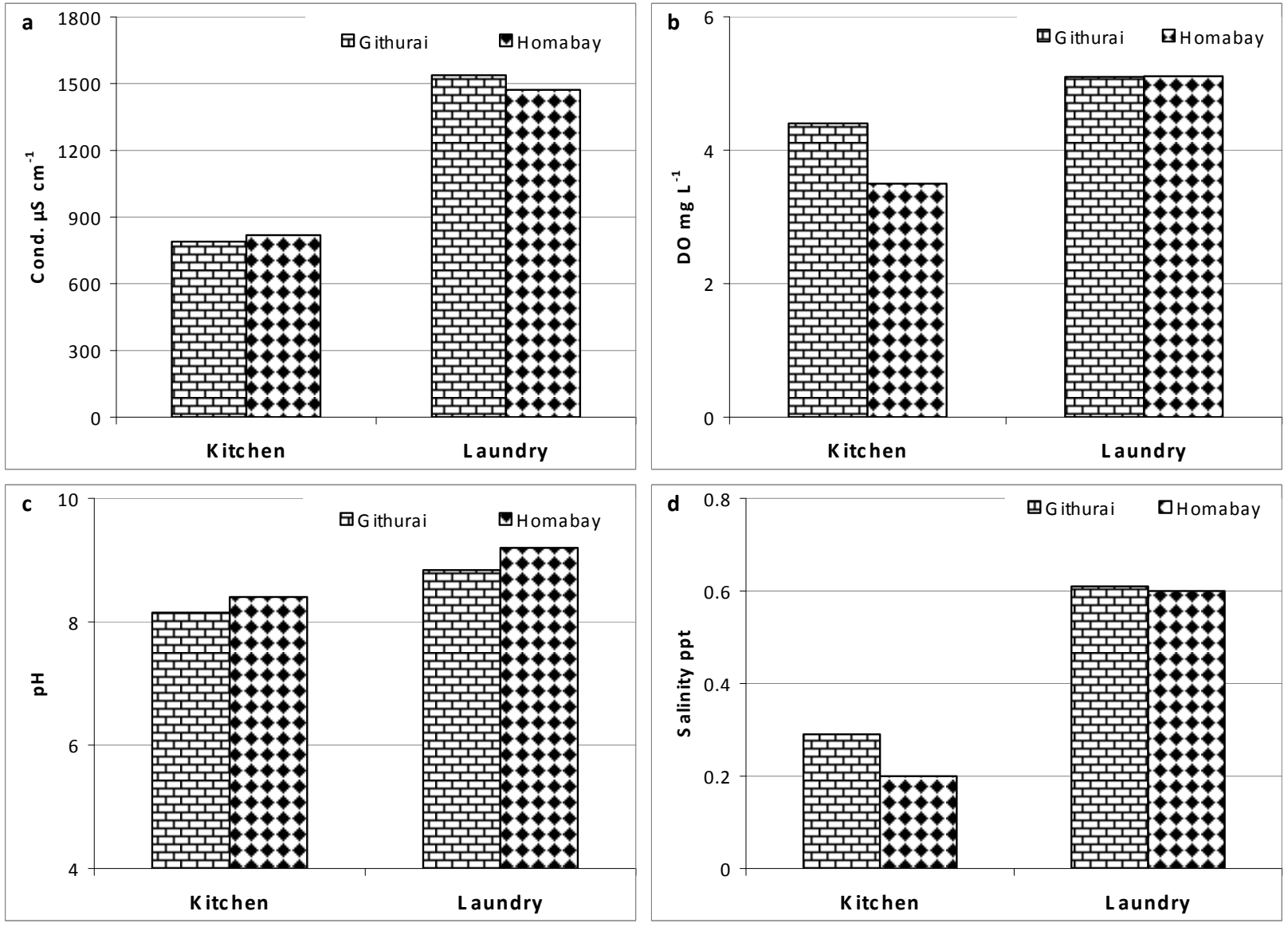

Fig. (2). Mean levels of conductivity (a), dissolved oxygen (b), salinity (c) and median pH (d) of kitchen and laundry greywater from Homabay and Githurai.

greywater was generally more saline than kitchen greywater (at $\mathrm{P}=0.05$ ). As in the case of EC above, a t-test revealed that the difference in mean salinity of the two sites (Fig. 2) was not significant $(\mathrm{P}=0.182$, df 137).
Dissolved oxygen (DO) concentration of greywater from Homabay and Githurai ranged from below the limit of detection (reported as 0.0 ) to $8.0 \mathrm{mg} \mathrm{L}^{-1}$ with mean range from 3.5 $\mathrm{mg} \mathrm{L}^{-1}$ (Homabay, kitchen) to $5.2 \mathrm{mg} \mathrm{L}^{-1}$ (Githurai, laundry). 

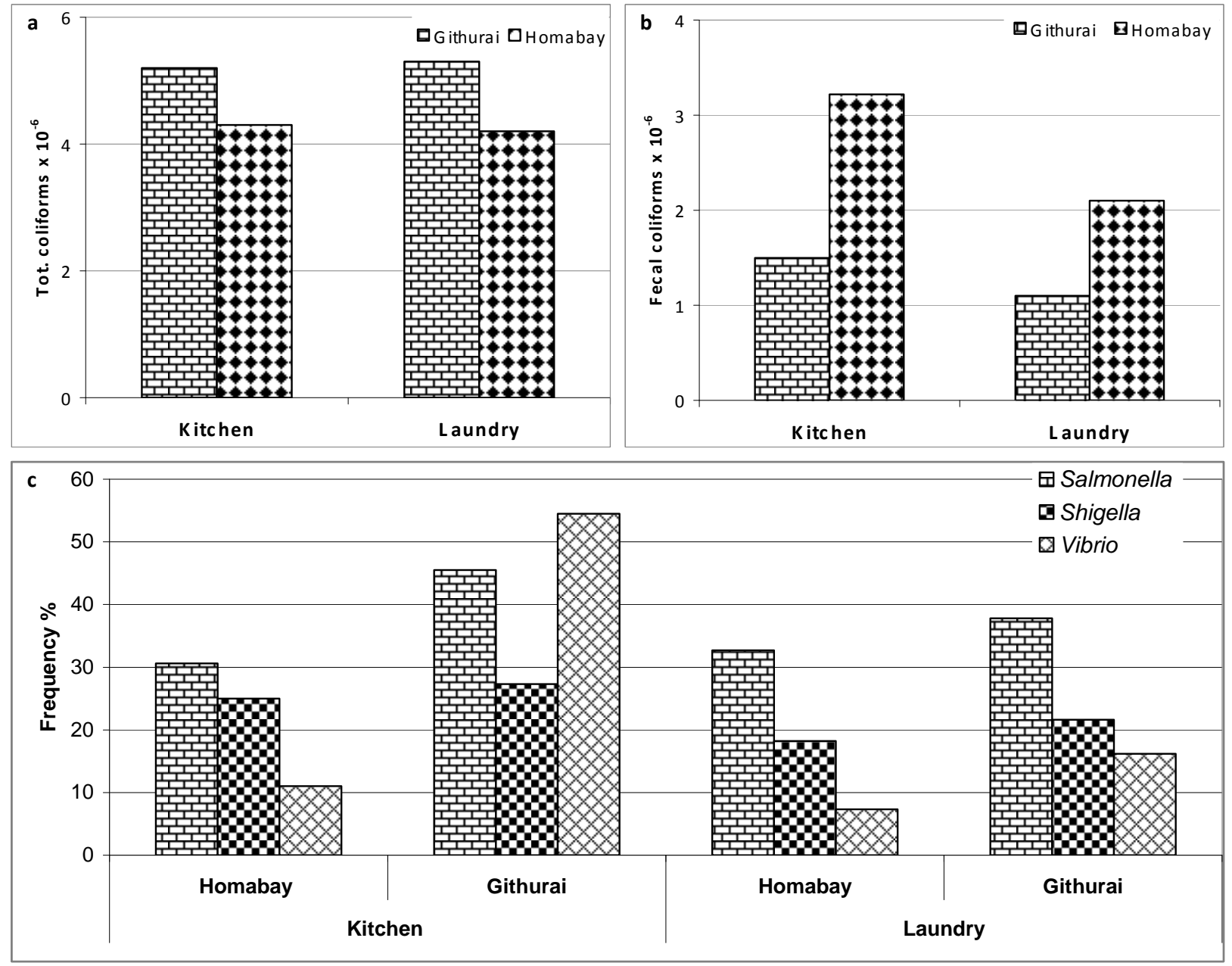

Fig. (3). Mean levels of total coliforms (a) and fecal coliforms (b) and percentage occurrence of pathogenic bacteria (Salmonella, Shigella and Vibrio cholerae) (c) in kitchen and laundry greywater from Homabay and Githurai.

The clean water sources sampled at both sites had higher DO values ranging from 4.1 to $7.7 \mathrm{mg} \mathrm{L}^{-1}$. Comparison of mean DO of all greywater types from the two sites using the ANOVA test revealed that the difference in DO was significant $(\mathrm{P}=0.01$, df 88). Mean separation using the LSD technique revealed that laundry greywater from Githura had a significantly higher DO than the kitchen and laundry greywater from Homabay (at $\mathrm{P}=0.05$ ). A t-test comparison of mean DO of greywater from Githurai and Homabay revealed that the difference in DO was significant $(\mathrm{P}=0.002$, $\mathrm{df}=90)$ with DO values at Githurai being generally higher (Fig. 2).

Greywater $\mathrm{pH}$ values varied widely with a range from 4.5 to 10.3 and median values of 8.2 for kitchen greywater from both sites, and 8.8 and 9.2 for laundry greywater from Githurai and Homabay sites respectively. Clean water samples recorded a lower $\mathrm{pH}$ range of between 6.7 and 7.5. Overall, kitchen water generally had slightly lower $\mathrm{pH}$ values compared to laundry greywater (Table 1, Fig. 2).

In Homabay, greywater temperatures at the time of collection ranged from 13.6 to $27.8^{\circ} \mathrm{C}$ with mean values of 26.2 ${ }^{\circ} \mathrm{C}$ (kitchen) and $24.9{ }^{\circ} \mathrm{C}$ (laundry). At Githurai, greywater temperatures at the time of collection ranged from 15.3 to $26.4{ }^{\circ} \mathrm{C}$ with mean values of $24.4{ }^{\circ} \mathrm{C}$ (kitchen) and $24.9{ }^{\circ} \mathrm{C}$ (laundry) (Table 1, Fig. 2). Clean water temperatures at the time of sampling varied between $20.0^{\circ} \mathrm{C}$ and $27.4{ }^{\circ} \mathrm{C}$ a both sites.

\section{BACTERIAL PROPERTIES}

\section{Total Coliforms}

Total coliform (TC) counts in greywater samples from Homabay ranged from $1.3 \times 10^{6}$ to $7.6 \times 10^{6}$ colony forming units (CFU) per $100 \mathrm{~mL}$, with mean values of $4.3 \times 10^{6}$ CFU/100 mL (kitchen) and $4.2 \times 10^{6} \mathrm{CFU} / 100 \mathrm{~mL}$ (laundry). In Githurai, TC counts in greywater ranged from $2.8 \times 10^{6}$ to $7.8 \times 10^{6} \mathrm{CFU} / 100 \mathrm{~mL}$ with mean values of $1.5 \times 10^{6}$ CFU/100 mL (kitchen) and $1.1 \times 10^{6} \mathrm{CFU} / 100 \mathrm{~mL}$ (laundry) (Table 1, Fig. 3). In general, higher TC counts were common in greywater from Githurai as compared to Homabay (Table 1, Fig. 3). A comparison of the mean TC counts of greywater samples from kitchen and laundry cleaning at the two sites using the ANOVA test revealed that the mean TC count difference was significant $(P=0.003, \mathrm{df}=122)$. LSD mean separation $(P=0.05)$ revealed that Githurai greywater had a significantly higher TC count than Homabay greywater. Comparison of mean TC of greywater from Githurai and Homabay using a t-test confirmed that difference in TC between the two sites was significant $(P=0.003, \mathrm{df}=122)$ with TC values at Githurai being higher. Clean water sam- 
ples from the two sites had lower TC counts ranging from $1.1 \times 10^{6}$ to $2.4 \times 10^{6} \mathrm{CFU}$.

\section{Fecal Coliform}

Fecal coliform (FC) counts in greywater from kitchen and laundry cleaning at Homabay ranged from $2.9 \times 10^{3}$ to $7.4 \times 10^{5}$ colony forming units (CFU)/100 mL with means of $2.1 \times 10^{5} \mathrm{CFU} / 100 \mathrm{~mL}$ (laundry) and $3.2 \times 10^{5} \mathrm{CFU} / 100 \mathrm{~mL}$ (kitchen). At Githurai, fecal coliform counts in greywater ranged from $2.9 \times 10^{3}$ to $6.2 \times 10^{5} \mathrm{CFU} / 100 \mathrm{~mL}$ with means of $1.1 \times 10^{5} \mathrm{CFU} / 100 \mathrm{~mL}$ (laundry) and $1.5 \times 10^{5} \mathrm{CFU} / 100$ $\mathrm{mL}$ (kitchen) (Table 1, Fig. 3). Fecal coliforms were not detected in clean water samples from both sites. A comparison of the mean FC counts of greywater types using the ANOVA test revealed that the difference in FC counts was not significant $(P=0.07, \mathrm{df}=135)$. However, a t-test analysis of the mean FC counts of greywater from Githurai and Homabay revealed a significant difference $(P=0.03, \mathrm{df}=137)$ with Homabay having higher FC counts than Githurai.

\section{Pathogenic Bacteria}

Salmonella, Shigella and Vibrio cholerae were occasionally present in the greywater samples investigated in the two study sites. The frequency of occurrence of Salmonella varied between $31 \%$ and $46 \%$ recorded in kitchen greywater samples from Homabay. Occurrence of Shigella varied between 18\% (Homabay laundry) and 25\% (Githurai kitchen) while Vibrio cholerae had a wider percentage range from 7.3 (Homabay laundry) to 55\% (Githurai kitchen) (Fig. 3).

\section{DISCUSSION}

A wide variation in the physico-chemical properties of greywater samples in Homabay and Githurai is a common characteristics of greywater [23, 27] and can been attributed to numerous factors that include the original quality of the water received at the home, personal hygiene of the family members, the number of occupants, age distribution of the members, their lifestyle, type of chemical products used, differences in the intensity of use of water before it qualifies to be discarded as well as the variation in the nature of dirt that the items being cleaned are exposed to. A unique feature of the two sites is the wide range in EC (range, 60 to 4650 $\mu \mathrm{S} \mathrm{cm}{ }^{-2}$ ). The range recorded falls outside the typical range of $325-1140 \mu \mathrm{S} \mathrm{cm}^{-2}$ for greywater [1]. A narrow range from $613-1890 \mu \mathrm{S} \mathrm{cm}^{-2}$ has been reported for households in Denmark ([28]. In a similar non-sewered area of South Africa (eThekwini Municipality), greywater EC ranged from 1440 to $2670 \mu \mathrm{S} \mathrm{cm}^{-2}$ [29]. The wide range of EC recorded may be the combined effect of diverse sources of domestic water (borehole, tap, lake and rainwater) as well as a wide variation in the concentration of greywater discharged. Comparatively higher EC of laundry greywater (mean values; $1472 \mu \mathrm{S} \mathrm{cm}^{-2}$ and $1538 \mu \mathrm{S} \mathrm{cm}^{-2}$ at Githurai and Homabay respectively), which resulted in a significant difference in EC of laundry and kitchen greywaters (Table 1) can be attributed to the use of chemical detergents which have a high concentration of dissolved ions in laundry cleaning. A higher ionic load of laundry greywater is confirmed by the greater salinity of greywater (mean values, $0.6 \mathrm{mg} \mathrm{L}^{-1}$ at both Githurai and Homabay) as compared to that of kitchen greywater and the water sources. Low EC of source water samples at both sites $\left(151.2 \mu \mathrm{S} \mathrm{cm} \mathrm{cm}^{-2}\right.$ at Githurai and 162.3 $\mu \mathrm{S} \mathrm{cm}$ at Homabay) confirms that the high EC of greywater was brought about by the cleaning process. However, there were some incidences when the greywater had an unusually low EC $\left(60 \mu \mathrm{S} \mathrm{cm}^{-2}\right)$. It is suspected that the greywater sample with low EC could have been directly harvested rainwater.

At both Githurai and Homabay, EC and salinity ranges for greywater in each of the two types of cleaning (kitchen and laundry) was more or less within the same range suggesting that there is no major difference in the water use behavior of communities at both sites. This may be because the two residential areas covered by the study had the same level of income, similar lifestyle and suffer the same water availability challenges. However, a significant difference in EC and salinity of greywater from different types of cleaning (kitchen and laundry cleaning) can be attributed to the possible difference in the quantity of dissolved ions in the detergents used for cleaning in each case. According to the standard classification of EC of greywater, the greywater from the two sites are mostly within the range of non saline $(0-$ $2,000 \mu \mathrm{S} \mathrm{cm}^{-1}$ ), with a few cases falling within the slightly saline range $\left(4,000-8000 \mu \mathrm{S} \mathrm{cm}^{-1}\right)$. Hence if the greywater is used for garden irrigation for a prolonged period of time, soil EC may increase progressively and after a long period of time, sensitive plants could suffer salt injury $[2,30]$. However, since the two areas regularly receive rainfall, the accumulated salts can be regularly flushed. Usually, salinity effects are generally of concern in areas where the accumulated salts are not regularly flushed from the soil profile by rainfall. Problems associated with salinity are caused by the accumulation of salts in the effective crop root zone and adversely affecting plant growth. Excess salts in the effective crop root zone hinder plant roots from withdrawing water from the surrounding soil and this lowers the amount of water available to the plant, regardless of the amount of water in the effective crop root zone [31]. Mean greywater EC values obtained at the two sites (789 to $1539 \mu \mathrm{S} \mathrm{cm}^{-2}$ ) are within the same range as that of greywater from other water scarce areas. Greywater studies carried out in Squ and Al Hail in Oman recorded mean EC values of $817 \mu \mathrm{S} \mathrm{cm}^{-2}$ and $1045.2 \mu \mathrm{S} \mathrm{cm}^{-2}$ for the two sites respectively [32]. In Amman, a mean EC of $1910 \mu \mathrm{S} \mathrm{cm}$ has been reported. The high conductivity of greywater is an indication of a high content of dissolved ions brought about by the very low per capita water consumption leading to the production of concentrated greywater. If the greywater generated in the two sites is to be applied in irrigated agriculture, the mean EC values recorded places the greywater generated in the class of irrigation water whose prolonged use in irrigation would result in moderate to severe impacts on the soil ([17]. However, since the suitability of water for irrigation greatly depends on the climatic conditions, physical and chemical properties of the soil, the salt tolerance of the crop grown and the management practices ([17]; further work will need to be carried out to establish the likely impact of the greywater generated on soils in the two areas. An evaluation of the chemical properties and biological activity in soils in the Mediterranean island of Mallorca following twenty years of treated wastewater irrigation revealed that the treatment did not have any negative effects on the measured soil parameters [33]. 
However, other studies have indicated that the long-term irrigation of surfactant-rich laundry greywater may create water-repellent soil with significant impact on agricultural productivity and environmental sustainability [34]. Hence further studies on the impact of greywater on soils needs to be carried out.

In the present study, mean greywater DO values of 3.5 to $5.2 \mathrm{mg} \mathrm{L}^{-1}$ confirms that the degradation of organic matter content of greywater commences immediately. Hence the prolonged storage of greywater can be a problem as anoxia and its associated problems are likely to set in. Studies on changes in DO during storage have shown that storage beyond 48 hours leads to DO depletion and results in aesthetic problems [35]). An important characteristic of greywater is the possession of easily biodegradable organic matter [10]. Hence some initial aeration may substantially reduce the organic matter load. Aeration of greywater before discharge into the environment has been suggested as a means of reducing the toxicity associated with deoxygenation [23]. Reasons for the higher DO values of greywater from Githurai as compared to those from Homabay are not clear and may require further investigation. Based on $\mathrm{pH}$ measurements, most greywater samples had $\mathrm{pH}$ values that do not pose a serious threat to soils and vegetation if discharged directly to the environment as only a few cases of low (4.5) and high (10.3) $\mathrm{pH}$ values were recorded. A $\mathrm{pH}$ range from $6.5-8.4$ is considered to have a minimum impact on the environment [17, 36]. Comparatively higher $\mathrm{pH}$ values of the laundry greywater (median $\mathrm{pH}$ 8.3) compared to kitchen greywater (median $\mathrm{pH}$ 8.2) can be attributed to the higher alkalinity of the detergents and soaps used [37]. Sodium, potassium and calcium form alkaline chemicals and their presence in laundry detergent, tends to raise alkalinity of the greywater. The low $\mathrm{pH}$ values recorded were mostly from kitchen washing and possibly resulted from occasions when the dishes with food remains were soaked overnight and washed in the morning.

Total coliform (TC) and fecal coliform (FC) bacteria have a long history of use as bacterial indicators of fecal contamination and possible presence of pathogenic bacteria. At both Homabay and Githurai, higher total coliform (TC) and fecal coliform (FC) counts in greywater as compared the same in water sources (Table 1) confirms that household cleaning generally increases the bacterial load of wastewater. Another contribution to the high load of TC and FC bacteria is the rapid bacterial built up in greywater, which results from the presence of a high load of easily degradable organic matter that favors the growth. Among the factors that have been identified to contribute to a wide variation in $\mathrm{TC}$ and FC counts are differences in household hygiene conditions as well as the greywater concentration [18]. Variation in greywater concentration is brought about by difference in water economy exercised by households. During periods of limited water availability, households, especially in low income areas tend to use water sparingly and in some cases recycle the same to a point where the dirt concentration is very high. Soaking of items for prolonged periods is also a common practice that serves to increase bacterial load of greywaters. During the study, it was observed that a number of households usually soak used utensils overnight. Food remains provide an excellent growth medium for bacteria contribut- ing to the high counts recorded. Reasons for the comparatively higher mean TC counts in kitchen $\left(5.23 \times 10^{6}\right.$ CFU/100 mL) and laundry $\left(5.35 \times 10^{6} \mathrm{CFUs} / 100 \mathrm{~mL}\right)$ greywater samples from Githurai are not clear and may reflect a higher environmental load of bacteria. However, lower FC counts at Githurai $\left(1.5 \times 10^{5}\right.$ and $1.1 \times 10^{5} \mathrm{CFUs} / 100 \mathrm{~mL}$ for kitchen and laundry respectively) as compared to Homabay suggests that the higher TC count may not be the result of fecal contamination. Overall, a wide range in TC (1.3 - 7.8 million CFU) is consistent with greywater TC observations made elsewhere. For example, Rose et al. [38] reported a TC range of between $10^{4}$ and $10^{6} \mathrm{CFU}$ per $100 \mathrm{~mL}$ while Cassanova et al. [39] found higher concentrations and reported a mean of $8.03 \times 10^{7} \mathrm{CFU}$ per $100 \mathrm{~mL}$ in their study. A comparatively lower range from $2400-2.4$ million CFU has been cited for the Dome distribution system, in London [40]. While some of these differences in TC counts can be attributed to different detection methods, a major source is the tremendous variability found in the composition of greywater. The presence of fecal coliforms, which are usually considered to be specific indicators of fecal contamination [41] and a possible presence of pathogens, suggests that greywater from the two sites is possibly contaminated fecal matter. Cross fecal contamination has been attributed to activities such as washing of fecally contaminated laundry (i.e. diapers), child care, anal cleansing and showering [1]. Overall, a FC range of between $2.9 \times 10^{3}$ and $7.4 \times 10^{5}$ recorded at the two sites exceeds the recommended maximum acceptable load for treated wastewater that can be used for irrigation of crops likely to be eaten uncooked or for sports fields and public parks [1]. Hence disinfection before use for irrigated agriculture is necessary.

Presence of specific enteric pathogens (Salmonella, Shigella and Vibrio) in varying proportions in different greywater types (Fig. 3) tested confirms the prevalence of diseases associated with these pathogens in the two sites. A notable observation was the occurrence of Vibrio cholerae in nearly $55 \%$ of all the kitchen water samples collected a Githurai. It is suspected that a cholera outbreak may have occurred at Githurai during the study period. Among the three pathogens investigated, Salmonella, which is usually associated with food poisoning, was the most frequent in all greywater samples $(31 \%-46 \%)$ investigated. The contamination of greywater by Salmonella usually occurs when an infected person washes or when contaminated food is washed [41]. Salmonella usually causes typhoid fever which is common in the study areas. The main reservoirs for human infection are poultry, cattle, sheep and pigs. Salmonella spp are common in animal feces and wastes from slaughter houses and poultry processing plants [40]. The presence of opportunistic pathogens in greywater indicates that inadequately treated and disinfected greywater may pose a particular risk to vulnerable individuals within households re-using greywater, particularly for susceptible individuals, such as the elderly, young, and immune-compromised. Past studies have reported the presence of enteric pathogens such as Salmonella, Shigella and Poliovirus Type 1 in greywater and concerns about the potential for re-growth or persistence of these organisms has been raised ([38]. Thermotolerant coliforms have been found to be multiplied by between 10 and 100 times during the first 24 to 48 hours of storage [1]. The occa- 
sional to a regular occurrence of pathogenic bacteria in greywater samples from the two sites investigated demonstrates the risk associated with the handling of greywater at the two sites and confirms the need for the disinfection of greywater. Since the pathogenic bacteria were absent in most clean water samples collected during the sampling period, it is clear that contamination occurred in the course of the cleaning.

\section{CONCLUSION}

The following conclusions were made from the study.

1. The quality of greywater generated varies widely from one household to another depending on, among other factors, the general hygiene of households as well as the water use economy.

2. Greywater from different cleaning operations varied significantly in most of the quality attributes measured. Significant variation in greywater quality of Homabay and Githurai residential areas was recorded only in some of the attributes measured.

3. Owing to the poor bacteriological quality of greywater generated by households at Homabay and Githurai, direct re-use of the same should be discouraged.

4. As different cleaning operations and residential areas vary in the quality of greywater produced, unique treatment technologies should be designed for each type of greywater and each site.

\section{CONFLICT OF INTEREST}

None declared.

\section{ACKNOWLEDGEMENTS}

We are grateful to the Victoria Research Initative (VicRes) for financial support. Our sincere appreciation is due to the Residents of Homabay and Githurai for granting us access to their houses to collect water samples and support with the field work. We thank Stephen M. Gichobi of the Department of Plant and Microbial Sciences for assistance in the field and in the laboratory.

\section{REFERENCES}

[1] World Health Organization (WHO), Guidelines for the safe use of wastewater, excreta and greywater. Excreta and greywater use in agriculture. WHO: Geneva, vol. 4, 2006.

[2] A. Gross, N. Azulai, G. Oron, Z. Ronen, M. Arnold and A. Nejidat, "Environmental impact and health risks associated with greywater irrigation: a case study", Water Sci. Technol., vol. 52, pp. 161-169, 2005.

[3] World Bank, Data and Statistics in Water Supply and Sanitation, 2005. Available at: http://web.worldbank.org.

[4] H. Yang and K.C. Abbaspour, "Analysis of wastewater re-use potential in Beijing", Desalination, vol. 212, pp. 238-250, 2007

[5] M. Caigan, "CDC looks at links between wastewater and disease", Small Flows Quart., vol. 6, no. 3, pp. 18 -21, 2005.

[6] M. Abu-Madi, O. Braadbart, R. Al-Sa'ed, and G. Alaerts, "Willingness of farmers to pay for reclaimed wastewater in Jordan and Tunisia", Water Sci. Technol. Water Suppl., vol. 3, pp. 115-122, 2003.

[7] D. Fatta-Kassinos, I.K. Kalavrouziotis, P.H. Koukoulakis and M.I. Vasquez, "The risks associated with wastewater reuse and xenobi- otics in the agroecological environment", Sci. Total Environ., vol 409, pp. 3555-3563, 2011.

[8] F. Pedrero and J.J. Alarcón, "Effects of treated wastewater irrigation on lemon trees", Desalination, vol. 246, pp. 631-639, 2009.

[9] B. Jefferson, A. Palmer, P. Jeffrey, R. Stuetz and S. Judd, "Greywater characterization and its impact on the selection and operation of technologies for urban re-use". Bedfordshire: Cranfield University, 2003.

[10] P. Len, G. Zeeman, and G. Lettinga Eds, Decentralised Sanitation and Reuse: Concepts, Systems and Implementation, IWA Publishing: UK, 2001.

[11] M. Ahmed, S. Prathapar, A. Al-Jamrah, A. Al-Maskiri, and A. AlBelushi, "Greywater reuse in arid countries: problems and possibilities", Sultan Qaboos University, 2001.

[12] S. Welton, B. Borsari, S. Doherty, V. Kefeli and T. Reynolds, Greywater treatment at the Robert A. Macoskey Center: Assessment and approaches to a renovated system design, Community College of Vermont: Pennsylvania, 2005.

[13] L. Hernández, H. Temmink, G. Zeeman and C.J.N. Buisman, "Characterization and anaerobic biodegradability of greywater", Desalination, vol. 270, pp. 111-115, 2011.

[14\} E. Madungwe and S. Sakuringwa, "Greywater reuse: A strategy for water demand management in Harare?" Phys. Chem. Earth, Parts $A / B / C$, vol. 32, pp. 1231-1236, 2007.

[15] O.R. Al-Jayyousi, "Greywater reuse: towards sustainable management" Desalination, vol. 156, pp. 181-192, 2003.

[16] G. Boghos, "Adoption of greywater treatment and reuse technology in a cluster of six towns in lebanon", International Water Demand Conference, Jordan, 2004.

[17] US EPA, Guidelines for water reuse, U.S. Environmental Protection Agency: Washington DC, 2007.

[18] M. Halalsheh, S. Dalahmeh, M. Sayed, W. Suleiman, M. Shareef, M. Mansour and M. Safi, "Grey water characteristics and treatment options for rural areas in Jordan", Biores. Technol., vol. 99, pp. 6635-6641, 2008.

[19] G.P. Winward, L.M. Avery, R. Frazer-Williams, M. Pidou and P. Jeffrey, "A study of the microbial quality of grey water and an evaluation of treatment technologies for reuse", Ecol. Eng., vol. 32, pp. 187-197, 2008.

[20] J. Ottosson, "Faecal contamination of greywater - assessing the treatment required for hygienically safe reuse or discharge" Swedish Institute for Infectious Disease Control, 2003.

[21] J. Ottosson, Hygiene aspects of greywater and greywater reuse. Licentiate Thesis. Royal Institute of Technology, Department of Water and Environmental Microbiology, Stockholm, 2003.

[22] E.N. Nolde, "Greywater reuse systems for toilet flushing in multistory buildings-over ten years experience in Berlin", Urban Water, vol. 1, pp. 275-284, 1999.

[23] K. Kotut, V.G. Nganga and F.W. Kariuki, "Physico-chemical and microbial quality of greywater from various households in Homabay Town", Open Environ. Engi. J., vol. 4, pp. 162-169, 2011.

[24] M. Cheesbrough, "Medical laboratory manual for tropical countries", In: Microbiolaogy, Butterworths: London, 1985, vol. 2, pp. 212-213.

[25] APHA, Standard Methods for the Examination of Water and Wastewater, $20^{\text {th }}$ ed, American Public Health Association: Washington DC, 1998.

[26] S. Stavric, and B. Buchanan, "The isolation and enumeration of Vibrio vulnificus from fish and sea foods", Laboratory Procedure MFLP-73, Health Protection Branch, Ottowa, Canada, 1995.

[27] F.W. Kariuki, K. Kotut and V.G. Ngángá, "The Potential of a low cost technology for the grey water treatment", Open Environ. Eng. J., vol. 4, pp. 32-39, 2011.

[28] E.H. Eriksson, "Potential and problems related to reuse of water in households," Ph.D. Thesis, Technical University of Denmark, 2002

[29] L. Salukazana, S. Jackson, N. Rodda, M. Smith, T. Gounden, N. McLeod and C. Buckley, Re-use of greywater for agricultural irrigation, Paper presented at the Third International Conference on Ecological Sanitation, 2006.

[30] E. Eriksson, K. Auffarth, M. Henze and A. Ledin, "Characteristics of grey water", Urban Water, vol. 4, no. 1, pp. 85-104, 2002.

[31] S. Surendran and A. Wheatley, "Grey-water reclamation for nonpotable re-use", J. CIWEM, vol. 12, pp. 406-413, 1998.

[32] M. Ahmed, S.M. Prathapar, A. Al-Beslushi, M. Al-Haddabi and A. Al-Busiadi, Greywater reuse potential in Oman, Proceedings of 
$28^{\text {th }}$ International Hydrology and Water resources Symposium, Wollongong NSW Australia, 2003.

[33] M. Adrover, E. Farrús, G. Moyà and J. Vadell, "Chemical properties and biological activity in soils of Mallorca following twenty years of treated wastewater irrigation", J. Environ. Manag., vol. 95, pp. 188-192, 2012.

[34] A.H.M. Faisal Anwar, "Effect of greywater irrigation on soil characteristics", In: $2^{\text {nd }}$ International Conference on Environmental Science and Development 2011, IPCBEE vol. 4, pp. 15-18, 2011.

[35\} A. Dixon, D. Butler, A. Fewkes and M. Robinson, "Measurement and modelling of quality changes in stored untreated grey water" Urban Water, vol. 1, pp. 293-306, 2000.

[36] FAO, "Water quality for agriculture: irrigation and drainage paper 29 Rev. 1", Food and Agriculture Organization of the United Nations, Rome, 1985, pp. 174.
[37] D. Christova-Boal, R. E. Eden and S. McFarlane, "An investigation into greywater reuse for urban residential properties", Desalination, vol. 106, pp. 391-397, 1996

[38] J.B. Rose, G.S. Sun, C.P. Gerba and N.A. Sinclair, "Microbial quality and persistence of enteric pathogens in GW from various household sources", Water. Res., vol. 25, no 1, pp. 37-42, 1991.

[39] L.M. Casanova, C.P. Gerba and M. Karpiscak, "Chemical and microbial characterization of household Gray water", J. Environ. Sci. Health A., vol. 36 no. 4, pp. 395-401, 2001

[40] R.M. Maier, I.L. Peper and C.P. Gerba, "Environmental Microbiology", Academic Press: USA, 2000.

[41] R. Birks and S. Hills, "Characterisation of indicator organisms and pathogens in domestic grey water for recycling", Environ. Monit. Assess., vol. 129, pp. 61-69, 2007.

(C) Nganga et al.; Licensee Bentham Open.

This is an open access article licensed under the terms of the Creative Commons Attribution Non-Commercial License (http://creativecommons.org/licenses/by$\mathrm{nc} / 3.0 / \mathrm{g}$ ) which permits unrestricted, non-commercial use, distribution and reproduction in any medium, provided the work is properly cited. 